\title{
JURNALISME DAN BENCANA (Refleksi Peran Jurnalis dalam Liputan Bencana Gempa, Tsunami dan Likuifaksi Palu-Donggala)
}

\author{
Oleh Hartinah Sanusi \\ Jurusan Jurnalistik, Fakultas Dakwah dan Komunikasi \\ UIN Alauddin Makassar \\ Email: tinasanusi@uin-alauddin.ac.id
}

\begin{abstract}
Abstrak;
Studi-studi terkait jurnalis dan liputan bencana umumnya menunjukkan kritik tajam terhadap pola-pola dan etika peliputan yang menonjolkan dramatisasi dan seringkali mengeksploitasi korban bencana baik narasi maupun audio visual. Jurnalis memainkan peran yang sangat penting dalam setiap peristiwa bencana. Bukan sekedar tuntutan profesi, mengumpulkan data dan informasi di lokasi bencana dan menyebarluaskannya dalam bentuk berita di media massa. Lebih dari itu, jurnalis juga diharapkan menunjukkan peran-peran jurnalisme yang lebih baik. Sebuah kesadaran dari para jurnalis dalam meliput peristiwa bencana dengan perspektif yang beragam dan utuh. Bahwa persoalan bencana tidak hanya pada saat bencana itu terjadi, melainkan ketika bencana tidak terjadi, sebelum terjadi dan juga setelah bencana terjadi. Diskursus mengenai peran jurnalis dalam peristiwa bencana menjadi penting di tengah tingginya tingkat kerawanan bencana di tanah air. Tulisan ini mencoba mengkaji lebih jauh kecenderungan peran jurnalisme yang dimainkan para jurnalis dalam meliput peristiwa bencana gempa, tsunami dan likuifaksi di kota Palu dan sekitarnya.
\end{abstract}

Kata Kunci ;jurnalisme, liputan bencana, peran jurnalis, gempa-tsunami dan likuifaksi PaluDonggala.

\section{A. PENDAhULUAN}

\section{Latar Belakang}

Diskursus tentang peran jurnalis di masyarakat telah lama mengemuka dan jadi sebuah kajian menarik baik di kalangan praktisi media sendiri maupun lingkup akademik sebagai sebuah kajian studi jurnalisme atau studi media dan masyarakat. Gagasan mengenai peran jurnalis sangat erat kaitannya dengan konsep dan teori mengenai fungsi dan peran media. Mustahil mengkaji apa dan bagaimana peran jurnalis di masyarakat tanpa menelaah lebih jauh perkembangan jurnalisme melalui apa yang tersaji di media saat ini.

Di Indonesia, peristiwa bencana kerap menghiasi pemberitaan di media-media massa baik media konvensional maupun media online. Tak terhitung, mulai dari bencana alam seperti gempa bumi, tanah longsor, banjir bandang, letusan gunung berapi, angin kencang puting beliung, tsunami dan juga bencana likuifaksi yang pertama kali terjadi di Indonesia pada bencana 
Palu-Donggala akhir September 2018 lalu. Belum lagi bencana yang disebabkan oleh campur tangan manusia seperti kecelakaan pesawat, kebakaran hutan dan sebagainya. Sedikit banyak, hampir semua peristiwa bencana menimbulkan kerugian baik itu korban jiwa maupun materi.

Media diharapkan memainkan peran yang penting dalam setiap peristiwa bencana. Media massa menjadi penghubung bagi semua pihak-pihak yang berkepentingan, baik dalam situasi prabencana, pada saat bencana terjadi maupun pasca-bencana. Rattien (1990) menjelaskan media massa bisa berperan lebih jauh dalam mengedukasi khalayak tentang kebencanaan, meningkatkan kesadaran publik melalui isu mitigasi bencana, bagaimana menghadapi bencana dan melakukan evakuasi, termasuk berkontribusi dalam proses rekonstruksi pasca-bencana ${ }^{1}$. Implikasinya, tentu saja pada para jurnalis sebagai tokoh utama yang memainkan peran-peran penting tersebut di atas.

Namun demikian, penting dipahami bahwa jurnalis yang bertugas di lapangan bukanlah aktor pemeran tunggal dalam sebuah 'panggung' liputan bencana. Jurnalis tidaklah bekerja sendiri, apalagi jurnalis televisi yang harus berkoordinasi dengan produser lapangan dan bekerja sama dengan anggota tim liputan lainnya, seperti kameramen, master control dan lain-lain. Termasuk juga ada redaktur, produser program, editor, dan anggota tim redaksi lainnya ikut berperan dalam penyajian program liputan bencana. Dapat dikatakan institusi atau organisasi media sebagai tempat bernaung para jurnalis sedikit banyak ikut memengaruhi peran-peran yang dijalankan oleh jurnalis ${ }^{2}$.

Halnya media massa di Indonesia, sejauh ini banyak menuai kritik terkait peran media dalam liputan bencana. Berdasarkan hasil studi literatur sejumlah kajian penelitian, penulis menemukan beberapa kesimpulan belum optimalnya peran media di Indonesia dalam liputan bencana. Kualitas praktik jurnalistik yakni rendahnya skill jurnalis ${ }^{3}$ dalam meliput dan menyajikan peristiwa bencana menjadi sorotan utama. Tema pemberitaan media massa terutama penyiaran televisi juga cenderung menyajikan peristiwa bencana di tanah air secara seragam yakni digambarkan dramatis dan traumatis, eksploitasi kesedihan dan penderitaan korban secara berlebihan (jurnalisme air mata) ${ }^{4}$ dan sejumlah temuan lain yang mengarah pada kritik kegagalan media dalam menjalankan peran-peran jurnalisme dalam liputan bencana.

Hal-hal tersebut di atas, menjadi titik awal bagi peneliti untuk menelaah lebih jauh sebuah diskursus peran jurnalis di masyarakat terkait isu kebencanaan. Kajian ini sangat relevan mengingat sebagian besar wilayah Indonesia termasuk dalam kategori potensi rawan bencana 
cukup tinggi. Sehingga, isu kebencanaan masih menjadi salah satu isu yang dianggap penting bagi khalayak dan media.

\section{B. PEMBAHASAN}

\section{Jurnalisme, Peran Jurnalis dan Liputan Bencana}

Pendekatan yang paling mudah untuk memahami studi dan praktik jurnalisme adalah dengan melihat jurnalisme sebagai suatu profesi, suatu pekerjaan yang berhubungan dengan pemberitaan di media massa. Di Indonesia, profesi jurnalis lebih dirinci dalam Undang-undang No. 40 tentang Pers, pasal 1 dinyatakan :

kegiatan jurnalistik meliputi mencari, memperoleh, memiliki, menyimpan, mengolah, dan menyampaikan informasi baik dalam bentuk tulisan, suara, gambar, suara dan gambar serta data dan grafik maupun dalam bentuk lainnya dengan menggunakan media cetak, media elektronik, dan segala jenis saluran yang tersedia ${ }^{4}$.

Terkait peran jurnalis, secara implisit sebenarnya dapat dilihat dari fungsi dan peranan pers nasional yang tertuang dalam pasal 3 dan 6 (ayat a-e). Antara lain disebutkan bahwa pers nasional berfungsi sebagai media informasi, pendidikan, hiburan dan kontrol sosial.

Dalam hal ini, peneliti sependapat dengan Ecip (2007) bahwa diantara fungsi media lainnya, fungsi pendidikan lebih menonjol. Mendidik dalam arti luas sebenarnya sudah mencakup fungsi memberi informasi, menghibur, mengontrol, mewariskan budaya, merekatkan masyarakat dan lain-lain. Menurut Ecip :

Menjalankan fungsi mendidik dalam arti luas itu antara lain bermakna menjelaskan apa yang terjadi dengan berita daripada merasa penting karena menerima informasi yang paling awal ${ }^{5}$.

Deuze dan Witschge (2017) lebih spesifik mengaitkan jurnalisme dengan pekerjaanpekerjaan yang berhubungan dengan ideologi dan budaya kerja yang khusus. Jurnalisme menuntut standar-standar kerja dan nilai-nilai yang ideal, diantaranya menyiapkan pelayanan publik, berupaya obyektif, adil, dapat dipercaya, komitmen pada aktualitas dan kecepatan dalam menyajikan informasi, serta memiliki tanggung jawab sosial dan etika.

Jurnalisme juga berperan penting dalam masyarakat demokrasi. Schudson (2008) setidaknya melihat bahwa jurnalisme dapat berperan dalam penguatan demokrasi melalui fungsi informasi, investigasi, analisis, mobilisasi, menyediakan ruang dengan beragam perspektif dan forum-forum publik. Sebagaimana Kovach dan Rosenstiel (2014) yang meyakini jurnalisme 
memainkan peran dalam memengaruhi kualitas hidup, pikiran dan budaya, sehingga penting bagi jurnalis untuk memahami standar-standar profesi dan nilai berita sebagai elemen-elemen penting dalam jurnalisme.

Konsep mengenai peran jurnalis di masyarakat pertama kali dikemukakan oleh Cohen pada 1963 (McQuail, 2004). Ada dua konsep peran jurnalis, pertama konsep jurnalis netral (neutral reporter) yang mengacu pada gagasan pers sebagai pemberi berita, penafsir dan alat pemerintah. Dalam hal ini, pers menempatkan diri sebagai saluran atau cermin. Kedua, konsep peran pemeran-serta (participant) atau dikenal sebagai istilah the traditional fourth estate dalam pengertian pers sebagai wakil publik, pengkritik pemerintah, pendukung kebijakan, dan pembuat kebijakan. Sejak penelitian yang dilakukan Carey (1969), Janowitz (1975), Tuchman (1978) dan sejumlah peneliti lainnya menunjukkan jurnalis cenderung pada peran netral (neutral reporter) terkait unsur obyektivitas di dalamnya sebagai nilai utama profesi jurnalis ${ }^{6}$.

Lebih jauh, Wilhout dan Weaver (1986) dalam McQuail (20014) juga melakukan penelitian yang sama namun membedakan peran jurnalis ke dalam tiga kategori peran. Pertama, peran penafsir (interpretative/investigative role), yakni menganalisis dan menafsirkan masalah kompleks, meneliti tuntutan yang dikeluarkan pemerintah serta membahas kebijakan nasional yang berlaku. Kedua, peran penyebar informasi (informative disseminator role), meliputi tugas penyampaian informasi kepada publik secepatnya dan pemusatan perhatian pada khalayak terbesar dan peran penentang (adversary role $)^{7}$.

Perkembangan penelitian selanjutnya terkait peran jurnalis tidak lagi melihat pada kecenderungan kategori peran apa yang dominan, lebih jauh menganalisis variabel-variabel tertentu yang memengaruhi peran-peran tersebut. Deuze (2002) juga mengembangkan konsep perbedaan budaya pemberitaan di sejumlah negara-negara dunia terkait peran jurnalis. Bahwa, peran penjaga anjing (watchdog role) serta peran pemberi informasi dan investigasi (informational and investigation roles) secara berbeda, lebih melekat pada jurnalis di Inggris, Australia dan Amerika Serikat. Adapun jurnalis di Jerman dan Belanda, meski peran-peran tersebut tidak begitu kuat melekat namun mereka secara khusus memberi perhatian pada peran berpihak pada kaum yang kurang beruntung atau istilah sederhananya 'pro-rakyat' (pro-people) daripada sikap anti-pemerintah (anti-government).

Tandoc dan Takashi (2016) dalam penelitiannya mengenai pengalaman jurnalis dalam meliput bencana badai Typoon Haiyan yang menerjang Filipina pada November 2013 
mengidentifikasi sejumlah jurnalis yang bertugas di lokasi bencana sebenarnya juga sekaligus adalah sebagai korban. Jurnalis juga mengalami kehilangan, rasa takut, khawatir, kelaparan dan traumatik namun tertutupi oleh tanggung jawab moral dan tuntutan profesi yakni pekerjaan sebagai jurnalis. Richard dan Rees (2011) menggambarkan bagaimana jurnalis juga bernegosiasi dengan peran profesi mereka sendiri ketika meliput peristiwa bencana dan harus mengatasi beban psikologis dan emosional yang timbul ketika melaporkan situasi bencana. Lebih jauh, Cottle (2012) mengidentifikasi sejumlah jurnalis yang kembali ke lokasi bencana setelah masa penarikan (rolling) tim liputan bencana selesai, bukan hanya kembali untuk meliput kondisi pasca-bencana namun juga sekaligus membantu korban dan melakukan tugas-tugas kemanusiaan. Dalam kondisi ini, jurnalis bukan sekedar menjadi saksi, melihat langsung dengan mata kepala sendiri (seeing) namun juga ikut merasakan (being there).

Studi tentang bagaimana media meliput peristiwa bencana sebenarnya telah banyak diteliti dalam kajian-kajian media dan bencana. Kebanyakan hasil penelitian menunjukkan pola pemberitaan media-media mainstream dalam meliput bencana cenderung mengikuti pola-pola yang sudah umum yakni memberikan fokus lebih besar pada dampak peristiwa bencana yakni menggunakan perspektif korban, berapa banyak korban tewas dan luka, seberapa besar kerusakan materi yang ditimbulkan dan seterusnya (Houston dkk, 2012; Pantti dkk, 2012). Media seringkali gagal 'menyelami' penyebab peristiwa bencana bahkan kadang justru memperburuk situasi.

Graber dan Dunaway (2015) dalam Tandoc dan Takashi (2016;3) mengidentifikasi tiga tahap peliputan bencana yang sering dilakukan, tahap pertama ditandai dengan sejumlah spekulasi dimana jurnalis harus secepatnya melaporkan peristiwa bencana dengan kondisi belum mengetahui detil peristiwa, masih mengumpulkan potongan-potongan informasi. Tahap kedua, jurnalis mulai melaporkan peristiwa bencana dengan perspektif yang lebih utuh dan mengoreksi informasi-informasi sebelumnya yang kurang akurat. Tahap akhir, dalam meliput peristiwa bencana seringkali terjadi tumpang tindih dengan laporan-laporan sebelumnya, terlihat upayaupaya jurnalis dalam menempatkan perspektif peristiwa bencana (framing) dan fokus liputan mulai bergeser pada upaya penanganan pasca-bencana.

Di Indonesia, kajian-kajian penelitian media dan bencana mulai mendapat perhatian sejak bencana tsunami Aceh 2004. Kajian terutama pada tema-tema pemberitaan peristiwa bencana melalui analisis isi berita, etika peliputan peristiwa bencana, konstruksi atau representasi 
peristiwa bencana melalui analisis wacana dan framing (Wahyuni, 2008), hingga analisis fotofoto peristiwa bencana di media massa. Terdapat kecenderungan pemberitaan media-media di Indonesia masih menunjukkan euphoria dalam meliput peristiwa bencana. Nazaruddin (2015) menyebutkan media cenderung mengeksploitasi bencana dengan berbagai praktik dramatisasi korban demi kepentingan industri media.

Terkait peran media dalam peristiwa bencana di Indonesia, Masduki (2007) mengidentifikasi peran ganda media yang menonjol yakni peran informatif dengan menyebarkan informasi bencana secara intensif dan peran sosial karikatif melalui aktifitas pengumpulan dan penyaluran bantuan bencana. Arif (2010) menyebutkan kesenjangan antara harapan terhadap peran dan tanggung jawab dengan praktik media memicu munculnya kecaman dan kritik keras publik terhadap pemberitaan tentang bencana. Peran jurnalis bukan sekedar menyebarluaskan informasi peristiwa bencana, melainkan bagaimana menghadapi bencana terutama mengurangi resiko bencana (disaster risk reduction).

\section{Trend Pemberitaan Bencana Gempa, Tsunami dan Likuifaksi Palu-Donggala, Sulawesi Tengah}

Bencana gempa, tsunami dan likuifaksi di Palu-Donggala, Sulawesi Tengah terjadi pada 29 September 2018 dengan magnitude 7,7 SR. Diperkirakan telah memakan korban lebih dari 1500 jiwa dan sekitar 1000 jiwa lebih kemungkinan masih terkubur' ${ }^{9}$ Selama dua pekan pertama, peristiwa bencana Palu-Donggala terus mendapat sorotan hampir semua media baik cetak maupun penyiaran, termasuk media online. Penulis mengamati perkembangan umum pemberitaan bencana Palu-Donggala di sejumlah media melalui televisi, koran dan media online, baik nasional maupun lokal. Namun, adanya keterbatasan waktu dalam pengumpulan data maka penulis lebih khusus menyoroti pemberitaan di sejumlah media online nasional diantaranya tribunnews.com, detik.com, liputan6.com, kompas.com, tempo.co, dan cnnindonesia.com. Juga, media online lokal di kota Makassar seperti makassar.tribunnews.com dan di kota Palu sendiri yakni satusulteng.com, radarsultengonline.com dan paluekspres.fajar.id.

Penulis melakukan penelusuran berita dengan menggunakan kata kunci 'gempa dan tsunami Palu'. Hasil penelusuran menunjukkan tren pemberitaan peristiwa bencana gempa Palu di media online sangat tinggi sejak 28 September hingga Oktober 2018. Selama dua pekan pertama pasca peristiwa bencana, media online begitu intens meng-update perkembangan 
peristiwa tersebut. Meski dengan frekuensi pemberitaan yang beragam, namun kecenderungannya mengalami peningkatan (lihat grafik1). Adapun, media online yang menunjukkan frekuensi pemberitaan bencana gempa Palu paling menonjol selama Oktober 2018 yakni detik.com (786), dan cnnindonesia.com (435).

Lebih jauh, penulis mengamati secara umum selama satu pekan pertama peristiwa bencana gempa, tsunami dan likuifaksi Palu-Donggala, hampir semua media serentak menginformasikan adanya kejadian bencana gempa dengan kekuatan cukup besar mengguncang kota Palu dan sekitarnya. Meski, terjadi spekulasi terkait akurasi informasi peristiwa, karena belum bisa dipastikan apakah peristiwa tersebut adalah gempa tektonik yang disertai tsunami atau bukan. Namun, sejumlah media online dengan cepat mengkonfirmasi soal video yang beredar di masyarakat adalah benar merupakan kejadian gempa dan tsunami.

Adapun, pemberitaan bencana gempa dan tsunami Palu-Donggala di media online lokal kota Palu diantaranya satusulteng.com langsung menurunkan berita pada 28 September 2018, di hari kejadian bencana dengan mengutip pernyataan Kepala BMKG yang membenarkan peristiwa gempa berkekuatan 7,7 SR dan disusul terjangan tsunami setinggi kurang lebih 1,5-6 meter ${ }^{10}$.
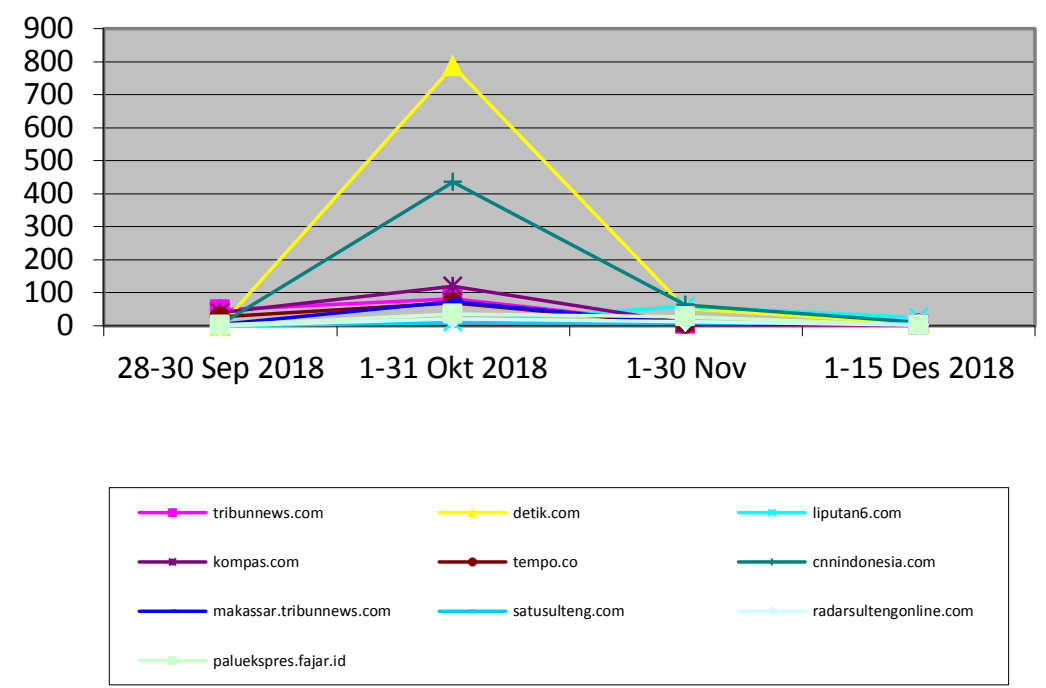

Grafik 1. Tren Pemberitaan Peristiwa Bencana Gempa, Tsunami dan Likuifaksi Palu-Donggala di Media Online (Sep-Des, 2018)

Selanjutnya, hingga akhir November 2018 perhatian media online pada peristiwa bencana di Palu mulai terus menurun. Pemberitaan bencana gempa, tsunami dan likuifaksi masih terlihat, namun tidak lagi se-intens sebelumnya. Hingga pekan ke dua Desember 2018, penulis 
mengamati tidak banyak media online yang konsisten mengikuti perkembangan aktivitas pemulihan kondisi kota Palu-Donggala pasca gempa, tsunami dan likuifaksi. Kecenderungan media dalam menyoroti peristiwa seringkali hanya pada saat peristiwa itu terjadi. Ketika ada peristiwa baru lainnya, perhatian media dengan cepat teralihkan.

\section{Grafik 2. Google Trends Isu Gempa, Tsunami dan Likuifaksi Palu-Donggala September- Desember 2018}

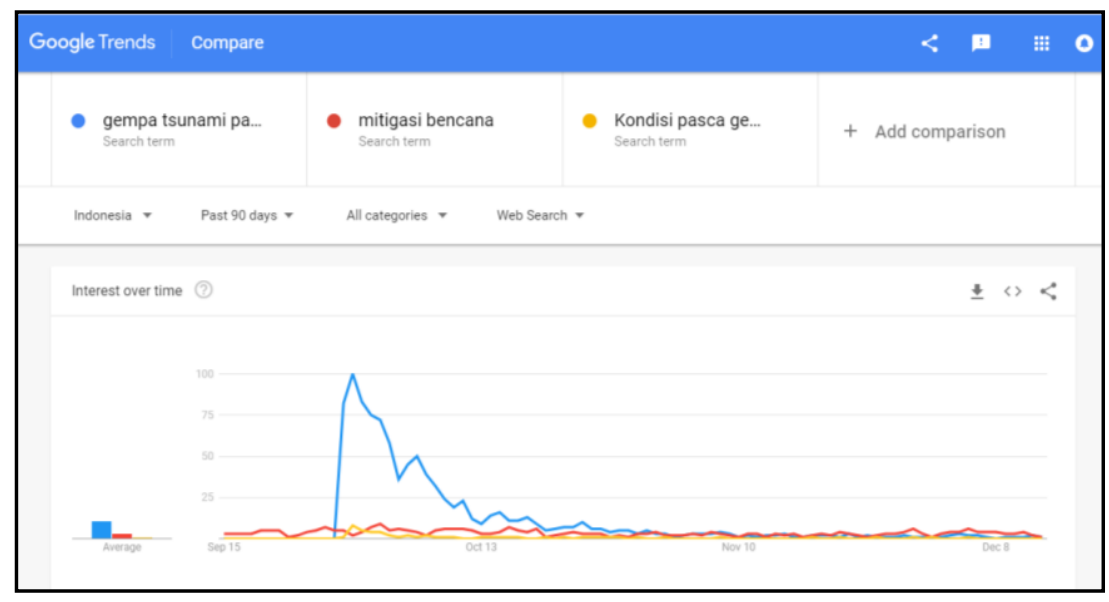

Selain grafik di atas, penulis juga menganalisis tren pemberitaan peristiwa gempa, tsunami dan likuifaksi Palu-Donggala melalui aplikasi google trends yakni grafik statistik pencarian web yang menampilkan popularitas topik pencarian dalam kurun waktu tertentu ${ }^{11}$. Berdasarkan aplikasi google trends, terlihat tren pencarian informasi sekitar bencana gempa, tsunami dan likuifaksi Palu-Donggala meningkat pada akhir September hingga pertengahan Oktober 2018. Namun tidak lama, tren pencarian topik gempa, tsunami dan likuifaksi Palu terus menurun hingga November dan Desember 2018, tergantikan oleh popularitas isu-isu atau peristiwa lainnya yang menarik perhatian khalayak.

Lebih jauh, penulis juga mencoba membandingkan dengan isu mitigasi bencana, terlihat memang tidak sebanding dengan peristiwa bencana itu sendiri. Pencarian isu seputar peristiwa gempa, tsunami dan likuifaksi Palu-Donggala jauh lebih tinggi daripada isu-isu terkait upaya pencegahan dan penanggulangan bencana atau mitigasi bencana. Artinya, khalayak belum banyak memberikan perhatian pada bagaimana mendeteksi bencana, bagaimana upaya mencegah korban lebih besar, termasuk bagaimana menghadapi bencana itu sendiri. Hal inilah, menurut penulis menjadi catatan penting bagi media untuk lebih mendorong praktik-praktik jurnalisme bencana yang lebih baik dan lebih optimis, bukan malah menjadi 'bencana' jurnalisme (Arif, 2010). 


\section{Refleksi Peran Jurnalis dalam Liputan Gempa, Tsunami dan Likuifaksi Palu-Donggala, Sulawesi Tengah.}

Dalam peristiwa bencana, jurnalis memainkan peran yang sangat penting terkait tanggung jawab profesi dan moralitas individu sebagai manusia. Dalam peristiwa gempa, tsunami dan likuifaksi Palu-Donggala, penulis mengamati kecenderungan peran jurnalis media online memang lebih dominan menunjukkan peran informatif atau penyebar informasi. Berdasarkan penelusuran penulis terhadap judul-judul pemberitaan di sejumlah media online, menunjukkan upaya para jurnalis dalam menggambarkan apa yang terjadi di lokasi bencana. Terlepas dari pemberitaan yang sifatnya spekulatif, jurnalis juga termasuk kelompok profesional pertama (first responder) yang berusaha sesegera mungkin berada di lokasi bencana tanpa menghiraukan kemungkinan resiko buruk yang mungkin dihadapi.

Peran informatif jurnalis terlihat mulai dari memastikan bahwa peristiwa di kota Palu dan sekitarnya benar adalah peristiwa gempa bumi yang diikuti dengan tsunami dan likuifaksi. Meski, penyebab simpang siurnya informasi peristiwa sebagian besar juga dikarenakan ulah jurnalis sendiri. Pada menit-menit pertama peristiwa gempa dan tsunami, umumnya jurnalis hanya mengandalkan sumber-sumber dari media lain, terutama media sosial melalui unggahan video amatir warga. Jurnalis biasanya melakukan kontak langsung dengan narasumber di kota Palu dan sekitarnya untuk memperoleh informasi yang lebih jelas. Kecuali, jurnalis yang memang berdomisili di wilayah yang sama dapat segera ke lokasi bencana dan langsung meliput bencana, meng-update perkembangan situasi dan kondisi di lokasi pasca-bencana.

Peran informatif lainnya yang cukup menonjol yakni penyebarluasan informasi terkait fenomena bencana yang belum pernah terjadi sebelumnya yakni likuifaksi. Jurnalis melalui ilmuwan ahli geologi berupaya menyampaikan ke masyarakat bahwa fenomena bergeraknya permukaan tanah kemudian amblas karena tanah berubah menjadi lumpur cair adalah peristiwa yang diidentifikasi sebagai likuifaksi. Meski, memang kedalaman informasi yang disajikan jurnalis cukup bervariasi bergantung pada model jurnalisme yang diusung media, juga ruang atau space khusus yang tersedia di laman media tersebut, misalnya kanal sains di kompas.com, kanal sains di liputan6.com, \#sains di kumparan.com, atau kanal teknologi di tempo.co dan di cnnindonesia.com. Selebihnya, informasi peristiwa likuifaksi muncul di kanal berita sebagai bagian dari peristiwa gempa dan tsunami saja. 
Selain itu, jurnalis juga cukup menunjukkan peran informatif lainnya melalui up-date informasi korban bencana, baik itu jumlah korban maupun kondisi sebagian besar korban bencana di kota Palu dan sekitarnya. Dalam hal ini, peran jurnalis lokal baik di kota Palu maupun Makassar sebagai lokasi pengungsian, menunjukkan peran informatif yang cukup besar dengan menyajikan liputan dalam perspektif lokal.

Lebih jauh, peran jurnalis lokal di kota Palu juga patut mendapat sorotan terkait upaya mereka menjalankan tugas dan tanggung jawab profesi jurnalis di tengah guncangan gempa dan gelombang tsunami. Jurnalis lokal umumnya memang memiliki peluang lebih besar sebagai first responder karena tinggal dan beraktifitas di kota Palu. Hasil penelusuran informasi di sejumlah media, penulis mencatat bahwa sejumlah jurnalis baik lokal maupun nasional juga terkena dampak langsung dari peristiwa gempa, tsunami dan likuifaksi Palu yakni ikut menjadi korban atau kehilangan anggota keluarga.

Jurnalis dituntut untuk bekerja secara profesional namun tidak mengesampingkan sisi kemanusiaan mereka. Bahwa jurnalis juga manusia biasa dan memiliki keluarga yang harus dilindungi. Hal inilah yang dihadapi sejumlah jurnalis televisi di kota Palu pada peristiwa gempa, tsunami dan likuifaksi. Seperti yang dikemukakan salah satu tokoh masyarakat sekaligus jurnalis senior di Palu, Erick Tamalagi :

"Apa yang dilakukan teman-teman para jurnalis TV di Palu, menurut saya, adalah kesadaran yang tinggi sebagai seorang jurnalis dan kepala keluarga....kegigihan terus meliput dan mencari spot untuk mengirimkan gambar di saat jaringan internet sangat terbatas dan membagi perhatian untuk keselamatan keluarga yang berada di pengungsian adalah perjuangan yang sangat patut kita hargai," ${ }^{12}$

Tercatat lima jurnalis televisi peliput gempa dan tsunami di Palu mendapatkan penghargaan dari Ikatan Jurnalis Televisi Indonesia (IJTI). Penghargaan itu diberikan karena aksi heroik mereka, salah satunya saat membantu warga Palu menyelamatkan diri dari tsunami. Mereka adalah Abdy Mari (tvOne), Ody Rahman (NET), Rolis Muhlis (Kompas TV), Jemmy Hendrik (Radar TV), dan Ary Al-Abassy (TVRI).

Pengalaman jurnalis televisi CNN Indonesia dalam meliput bencana di kota Palu dan sekitarnya dalam program spesial 'Kami Bersama Sulawesi Tengah' episode 19 Oktober 2018 lalu, sedikit banyak juga memberikan pemahaman betapa tidak mudahnya situasi yang harus dihadapi jurnalis di lokasi bencana. Jurnalis bukan hanya menghadapi kondisi kota PaluDonggala yang lumpuh, luasnya wilayah area yang terdampak bencana, termasuk juga luasnya 
sebaran posko-posko pengungsi, kondisi listrik padam, kekurangan air bersih, korban meninggal dan lain sebagainya. Melainkan, jurnalis juga harus menghadapi situasi yang tidak aman akibat penjarahan termasuk penghadangan kendaraan yang mengakibatkan lambatnya tim liputan samapi ke lokasi bencana ${ }^{13}$.

Meski demikian, dalam menjalankan peran-peran jurnalistik tim liputan bencana televisi CNN Indonesia selalu berupaya menghadirkan jurnalisme optimisme. Sebuah bentuk liputan bencana yang bisa memberikan dampak positif secara psikologis bagi korban dan keluarga korban serta masyarakat yang menyaksikan. Jurnalisme optimis dalam liputan bencana mampu berperan dalam pemulihan kondisi sosial masyarakat pasca bencana. Seperti di Jepang, praktik jurnalisme bencana yang optimis memberikan efek positif terhadap percepatan proses rehabilitasi dan pembangunan pasca gempa Sendai yang mencapai 8,9 SR pada Maret 2011 lalu $^{14}$.

Sejumlah jurnalis media online, seperti detik.com, tempo.com dan kompas.com juga menunjukkan upaya peliputan bencana yang lebih optimis dengan menyajikan pemberitaanpemberitaan yang informatif, mengedukasi dan memberikan semangat positif bagi pemulihan kota Palu dan sekitarnya. Meski, juga sekaligus memainkan peran karikatif dengan mengajak masyarakat untuk mengulurkan bantuan melalui program-program bantuan korban bencana Palu yang diorganisir oleh media yang bersangkutan, misalnya donasi dompet amal transmedia di Trans TV, Trans7, CNN Indonesia, Detik.com, CNNIndonesia.com, dan CNBCIndonesia.com.

Di samping peran informatif, jurnalis juga tampak memainkan peran kritik sekaligus peran anjing penjaga (watchdog) dalam peristiwa bencana gempa, tsunami dan likuifaksi di kota Palu dan sekitarnya. Meski, tidak banyak namun penulis mengamati sejumlah pemberitaan di media online, seperti tempo.co, dan satusulteng.com mengangkat isu belum adanya bantuan untuk para korban bencana di kota Palu dan sekitarnya, juga lambatnya distribusi bantuan serta tidak meratanya distribusi bantuan untuk para korban. Situasi dan kondisi di jalan-jalan menuju lokasi bencana yang berdampak luas pada ketidakamanan dan ketidaknyamanan warga, terkait tindakan penjarahan yang terjadi di sejumlah titik lokasi di tengah dan menuju kota Palu. Termasuk juga, santunan korban bencana yang belum cair dan fakta banyaknya relawan yang belum terlatih menghadapi situasi pasca-bencana.

Adapun, peran watchdog oleh jurnalis dapat diamati melalui pemberitaan terkait kebijakan pemerintah dalam penanganan korban pasca-bencana. Secara umum, peran jurnalis sebagai anjing penjaga dalam peristiwa bencana Palu memang tampak belum maksimal. 
Sebagian besar jurnalis media online hanya sampai pada peran penyebarluasan informasi terkait kebijakan pemerintah. Misalnya, pemberitaan kebijakan pemerintah terkait pembangunan hunian tetap (huntap) masih sebatas menginformasikan saja, belum sampai pada pengawasan implementasi kebijakan tersebut. Bagaimana progres pembangunannya termasuk kualitas dari hunian tersebut belum banyak diliput oleh jurnalis.

Melalui peran watchdog ini, jurnalis diharapkan ikut mengawasi dan mengawal semua kebijakan pemerintah terkait peristiwa bencana. Pengawasan pada saat tidak terjadi bencana (non disaster), sebelum terjadi bencana (pre-disaster), saat terjadi bencana (during disaster) dan pasca-bencana (post disaster). Jurnalis diharapkan mampu menyajikan informasi data yang akurat dan dapat dipertanggungjawabkan, sehingga bisa menjadi bahan rujukan bagi pemerintah dalam mengambil keputusan dan kebijakan yang tepat terkait penanganan bencana. Dengan demikian, media juga bisa menghadirkan jurnalisme bencana yang lebih mengedepankan etika dan optimisme, yang mendukung proses rekonstruksi dan rehabilitasi wilayah terdampak bencana dengan cepat dan membangun masyarakat ke arah yang lebih baik lagi.

\section{Simpulan}

Peristiwa bencana dalam jurnalisme memiliki nilai berita khusus, terkait waktu kejadian yang sulit diprediksi dan dampaknya yang luar biasa. Maka, jurnalis memiliki peran dan tanggung jawab yang besar dalam peristiwa bencana. Kecenderungan jurnalis terhadap peran informatif ditunjukkan dalam hampir setiap peristiwa bencana, termasuk bencana gempa, tsunami dan likuifaksi di kota Palu dan sekitarnya. Selain peran informatif, jurnalis juga menjalankan peran kritik dan atau peran watchdog, meski belum begitu maksimal. Diharapkan ke depannya, para jurnalis lebih memaksimalkan peran-peran jurnalisme yang positif dan optimis dalam peliputan bencana, baik sebelum bencana, pada saat bencana maupun pasca-bencana. Implikasi studi jurnalisme dan bencana ke depan, penulis berharap bisa mengkaji lebih jauh lagi peran jurnalis dalam liputan bencana melalui pendekatan fenomenologi dengan wawancara mendalam untuk mengurai persepsi dan pengalaman terkait identitas dan peran profesi jurnalis di masyarakat.

\section{Catatan Akhir}

${ }^{1}$ lihat Stephen Rattien. "The Role of the Media in Hazard Mitigation and Disaster Management". Disasters.

Vol.14

(1), 36-45

(March

1990). 
https://onlinelibrary.wiley.com/doi/abs/10.1111/j.1467-7717.1990.tb00970.x. (diakses 15 Desember 2018). h.1-2

${ }^{2}$ lihat Denis McQuail. Mass Communication Theory. 5-th edition. Sage Publications. London. 2005. h.284-285.

${ }^{3}$ Muzayyin Nazaruddin.’Jurnalisme Bencana : Sebuah Tinjauan Etis”. Jurnal Komunikasi. Vol.1 (2). 163-177 (April 2007). h.175

${ }^{4}$ Filosa Gita Sukmono dan Fajar Junaedi. "Jurnalisme Sensitif Bencana dalam Manajemen Pencarian, Pengelolaan Informasi dan Pemberitahuan Bencana di Ruang Redaksi”. Jurnal Aspikom. Vol.3(4). 712-721 (Januari 2018).h. 720

${ }^{5}$ Pasal 1 UU No. 40 tentang Pers

${ }^{6}$ S. Sinansari Ecip.Jurnalisme Mutakhir, Panduan dari atas Meja. Republika. Jakarta. 2007. h.8

7 lihat kembali Denis McQuail. Mass Communication Theory. 5-th edition. Sage Publications. London. 2005. h.285-287.

${ }^{8}$ Jamie Matthew. "Cultural Othernes and disaster news: The influence of western discourses on Japan in US and UK news coverage of the 2011 Great East Japan Disaster". The International Communication Gazette. $0 \quad$ (0). 1-21(May 2018). https://journals.sagepub.com/doi/abs/10.1177/1748048518774982. (diakses 28 November 2018). h.2-3

'baca lebih lanjut "Tsunami sudah menerjang Indonesia sejak tahun 416". (liputan berita). BBC News Indonesia. (7 Oktober 2018). https://www.bbc.com/indonesia/indonesia-45742383. (diakses 26 November 2018)

${ }^{10}$ buka link https://search.kompas.com/search/?q=gempa+dan+tsunami+Palu\&submit=Submit. (diakses 15 Desember 2018). Baca juga "Gempa 7,7 SR di Palu, Sigi, Donggala, Tsunami Hantam Palu dan Donggala". (liputan berita). Sulteng.com. (28 September 2018). http://www.satusulteng.com/gempa-77-sr-di-palusigi-donggala-tsunami-hantam-palu-dandonggala/ . (diakses 15 Desember 2018)

${ }^{11}$ lihat

https://trends.google.com/trends/explore?date=today $\% 203$ $\underline{m} \& g e o=I D \& q=$ gempa $\% 20$ palu,mitigasi\%20bencana,kondisi $\% 20$ pemulihan $\% 20 \mathrm{kota} \% 20$ palu. (diakses 17 Desember 2018)

${ }^{12}$ Baca berita "Penghargaan untuk lima jurnalis heroik peliput gempa Palu". (liputan berita). Kompas.com. (12 Oktober 2018). https://regional.kompas.com/read/2018/10/12/16461671/penghargaan-untuk-lima-jurnalisheroik-peliput-gempa-palu. (diakses 01 Desember 2018)

${ }^{13}$ lihat tayangannya di https://www.youtube.com/watch?v=kivTbBQoY9g.. (diakses 24 November 2018)

${ }^{14}$ baca lebih lanjut "Fakta Peristiwa Bencana Alam Tsunami Sendai 2011". Blog resmi ACT (Aksi Cepat Tanggap).blog.act.id (26 Mei 2015). https://blog.act.id/fakta-peristiwabencana-alam-tsunami-sendai-2011/. (diakses 16 Desember 2018)

\section{Daftar Pustaka}

Ali, Zarqa S, "Media, myths, and realities in natural disasters". European Journal of Business and Social Science. Vol.2 (1):125-133 (April 2013). http://www.ejbss.com/Data/Sites/1/vol2no1april2013/ejbss-1238-13mediamythsandrealitiesinnaturaldisasters.pdf.(diakses 11 November 2018)

Arif, Ahmad. Jurnalisme Bencana, Bencana Jurnalisme. Kompas Grup. Jakarta. 2010. 
Mendefinisikan Ulang Jurnalisme Bencana. Diperoleh di https://bnpb.go.id/uploads/24/seminar/Mendefinisikan_Ulang_Jurnalisme_Bencana.pdf. (diakses 21 November 2018)

Cottle, Simon. "Journalist witnessing disaster". Journalism Studies. Vol.14 (2): 232-248 (03 September https://www.tandfonline.com/doi/abs/10.1080/1461670X.2012.718556?journalCode=rjos 20. (diakses 18 November 2018)

Ecip, S.Sinansari. Jurnalisme Mutakhir, Panduan dari atas Meja. Republika. Jakarta. 2007

Deuze, Mark. "National News Cultures". Journalism and Mass Communication Quarterly. Vol.79(1):134-149

Maret 2002). https://journals.sagepub.com/doi/abs/10.1177/107769900207900110. $\quad$ (diakses 10 November 2018)

Houston, J. Bryan dkk. "Disaster news : Framing and frame changing in coverage of major U.S natural disastes, 2000-2010. Journalism and Mass Communication Quarterly. Vol.89:606623 $(20$ Agustus 2012). https://journals.sagepub.com/doi/abs/10.1177/1077699012456022. (diakses 18 November 2018)

Schudson, M. Why Democracies Need Unloveable Press.Polity Press, Cambridge. 2008

Kovach, Bill dan Tom Rosenstiel. Sembilan Elemen Jurnalisme. Jakarta : Pantau 2012.

Masduki. "Wajah ganda media massa dalam advokasi bencana alam". Jurnal UNISIA, No. 63/XXX/V/2007.Januari-Maret 2007.

Matthews, Jamie. "Cultural Othernes and disaster news: The influence of western discourses on Japan in US and UK news coverage of the 2011 Great East Japan Disaster". The International Communication Gazette. 0(0):1-21(May 2018). https://journals.sagepub.com/doi/abs/10.1177/1748048518774982. (diakses 18 November 2018).

- "The Role of local newspaper after disaster : an intrinsic case study of Ishinomaki, Japan”. Asian Journal of Communication. Vol.27 (5):464-479 (18 Januari 2017). https://www.tandfonline.com/doi/abs/10.1080/01292986.2017.1280065. (diakses 18 November 2018)

McQuail, Denis. Mass Communication Theory. 5-th edition. Sage Publications. London. 2005

Miller, Andrea dan Robert Goidel. "News Organizations and information gathering during a natural disaster : Lessons from Hurricane Katrina”. Journal of Contingencies and Crisis Management.Vol.17:266-273 (17 November 2009). https://onlinelibrary.wiley.com/doi/abs/10.1111/j.1468-5973.2009.00586.x. . (diakses 21 November 2018)

Nazaruddin, Muzayyin. "Jurnalisme bencana di Indonesia, setelah sepuluh tahun”. Jurnal Komunikasi. Vol.10 (1). ISSN 1907-898X. Oktober 2015.

Pannti, Mervi dkk. Disasters and the Media. Peter Lang, New York. 2012

Richards, Barry dan Gavin Rees. "The management of emotion in British Journalism". Media, Culture and Society. Vol 33 (6):851-867 (09 September 2011). https://journals.sagepub.com/doi/10.1177/0163443711411005. (diakses 20 November 2018) 
Smith, River dkk. "Covering trauma : impact on journalist". Artikel (01 Juli 2015). Dart Center for Journalism. https://dartcenter.org/content/covering-trauma-impact-on-journalists. (diakses 15 November 2018)

Tandoc, Edson C., dan Bruno Takashi. "Journalist are human, too : A phenomenology of covering the strongest storm on earth". Journalism.Vol.19 (7):917-933. https://journals.sagepub.com/doi/abs/10.1177/1464884916657518. (diakses 20 November 2018)

Veil, Sari R., "Clearing the Air : Journalist and emergency managers discuss disaster response. Journal of Applied Communication Research. Vol.40 (3):289-306 (07 Juni 2012). https://www.tandfonline.com/doi/abs/10.1080/00909882.2012.679672?.journalCode=rjac2 ‥ (diakses 20 November 2018)

Wahyuni, Hermin Indah. "Kecenderungan framing media massa dalam meliput bencana sebagai media event". JSP:Jurnal Ilmu Sosial dan Ilmu Politik. Vol.3 (11):307-330. 2008

https://www.bbc.com/indonesia

https://www.cnnindonesia.com/

https://www.detik.com/

https://www.kompas.com/

https://kumparan.com/

https://www.liputan6.com/

https://paluekspres.fajar.co.id/

http://radarsultengonline.com/

http://satusulteng.com/

http://www.tribunnews.com/nasional 